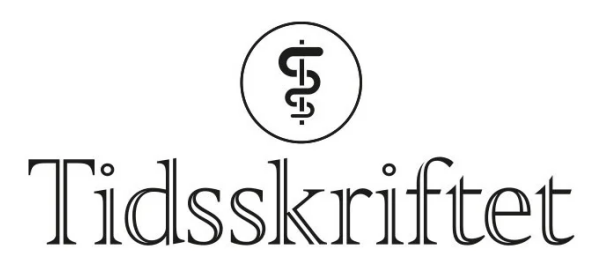

DEN NORSKE LEGEFORENING

\title{
Fellesskap på blå resept
}

\author{
FRA REDAKTØREN
}

\section{ELENA V. AANDSTAD}

elena.aandstad@tidsskriftet.no

Elena V. Aandstad er medisinsk redaktør i Tidsskriftet. Hun er allmennlege med spesialisering i allmennmedisin fra USA.

\section{Blåreseptordningen bidrar til å utjevne helseforskjeller. Sanksjoner mot leger for feilskrevne blåresepter passer dårlig med vår solidariske tanke om helse for alle.}

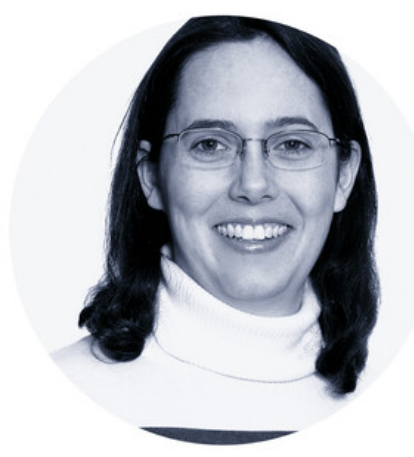

Foto: Sturlason

Som allmennlege i en liten landsby i Vermont i USA måtte jeg alltid ta hensyn til pasientens økonomi i valg av utredning og behandling. Var pasientens kols behandlingsresistent? Eller hadde han ikke råd til å kjøpe medisinene sine?

Vermont er en av de mer sosialdemokratiske delstatene i USA. Likevel ble jeg stadig minnet om at jeg jobbet i et system som var (under)finansiert av et lappeteppe av offentlige og private forsikringsordninger. Jeg møtte pasienter som ikke hadde råd til medisiner eller til å prioritere egen helse før tilstanden var helt akutt. En rapport fra 2021 viste at $30 \%$ av amerikanere unnlot å søke helsehjelp på grunn av utgiftene og at 14 \% ikke kunne betale for minst én av sine faste medisiner (1) . Når forsikringsselskaper betaler utgiftene, er det $\emptyset$ konomien som styrer. Fellesskapet - å betale for at alles helse skal tas vare på - blir et fjernt konsept.

Som lege i Norge er jeg glad for å arbeide i et system der helse ikke skal begrenses av pasientenes privatøkonomi. For det er det blåreseptordningen handler om: at vi har et fellesskap der alle skal kunne få helsehjelp når de trenger det. Lave tak for egenandeler for legebesøk, blåreseptordningen og frikortordningen gir kronisk syke muligheten til å prioritere egen helse uavhengig av privat økonomi eller forsikring. 
Men noen må ta regningen. Statlig kompenserte helsetjenester er et gode, og jo mer sofistikert behandlingen er, jo høyere forventninger har pasientene. Underveis øker prisen for fellesskapet. Allerede ved revisjonen av blåreseptordningen i 2004-06 ble manglende kostnadseffektivitet påpekt (2,, 3 ). Den gang skyldtes $15 \%$ av forskrivningsfeil manglende refusjonsvilkår (4). I perioden 2010-19 økte refusjonsutgiftene for legemidler forskrevet på blåresept med 30 \%, og i 2019 ble det omsatt legemidler over blåreseptordningen for 11,7 milliarder kroner (5).

Leger har et stort ansvar når de forvalter fellesskapets pengekasse. Manglende oversikt over refusjonsvilkår, manglende beslutningsstøtte, manglende bevissthet om portvokterrollen, tidspress og faglig uenighet kan være noen årsaker til feilaktig bruk av blåreseptordningen (5).

\section{«Gebyrordningen truer faglig forsvarlig pasientbehandling»}

Nå synes myndighetene altså at en bra måte å spare kostnader knyttet til blåreseptordningen på er å straffe leger som oppgir feil refusjonsvilkår (므). Innføringen av et overtredelsesgebyr trådte i kraft 1.1.2022, trass i gjentatte protester fra Legeforeningen (7,8). Å gjøre blåreseptordningen til en konflikt mellom helsemyndigheter og leger er et skritt i feil retning. Det er ikke legen som vinner økonomisk på forskrivningsfeil, men pasienten. Gebyrordningen truer faglig forsvarlig pasientbehandling. Vi bør heller sammen se på hvorfor det er behov for så mange legemidler, og hvordan vi kan øke satsningen på forebyggende helsetiltak slik at færre blir kronisk syke.

Balansen mellom legens rolle som forvalter og pasientens behandler er i ferd med å bli vanskeligere enn den har vært. Fellesskapet er også avhengig av legers empati for medmennesker og motivasjon for å fortsette i helsetjenesten. Blir man straffeforfulgt dersom man ikke hele tiden er skeptisk til pasientens troverdighet, synker motivasjonen for å finne ut av faglige avveiinger der medisinske gråsoner dukker opp. Fastlegeordningen lider allerede. Å innføre overtredelsesgebyrer og øke videre byråkratisering vil ikke hjelpe rekrutteringen av leger til allmennpraksis (9.).

For å kunne fylle våre mange roller som lege må vi få tillit til å utøve vårt yrke til fellesskapets beste.

\section{LITTERATUR}

1. West Health-Gallup. 2021 Healthcare in America Report.

https://www.gallup.com/analytics/357932/healthcare-in-america-2021.aspx Lest 15.1.2022.

2. Høringsnotat - revisjon av blåreseptordningen. Forslag til ny blåreseptforskrift og endringer i legemiddelforskriften m.v.

2006. https://www.regjeringen.no/globalassets/upload/kilde/hod/hdk/2006/oo10/ddd/pdfv/300827horingsnotat_om_blaresept.pdf Lest 16.1.2022.

3. Sundar T, Thuestad AB, Thomassen PT et al. Blåreseptordning i skrøpelig forfatning? Tidsskr Nor Lægeforen 2006; 126: 1759-61. [PubMed]

4. Haavik S, Horn AM, Mellbye KS et al. Forskrivningsfeil-omfang og oppklaring. Tidsskr Nor Lægeforen 2006; 126: 296-8. [PubMed]

5. Vista-analyse. Riktige legemidler til rett pris. Områdegjennomgang av legemidler under folketrygden. VA-rapport

2021/o1. https://www.regjeringen.no/contentassets/64131807ce574a6db6ccb5f321dd3629/riktigelegemidler-til-rett-pris.pdf Lest 14.1.2022.

6. Helsedirektoratet. Rundskriv til folketrygdloven $\S 25-6$ a - retningslinje for ileggelse og utmåling av overtredelsesgebyr. 1.1.2022. https://www.helsedirektoratet.no/rundskriv/rundskriv-tilfolketrygdloven--25-6-a--retningslinje-for-ileggelse-og-utmaling-av-overtredelsesgebyr Lest 17.1.2022.

7. LOV-1997-02-28-19. Lov om folketrygd - § 25-6 a. Overtredelsesgebyr. Tilføyd ved lov 21 juni $2019 \mathrm{nr}$. 42 (ikr. 1 jan 2022 iflg. res. 17 sep 2021 nr. 2767). https://lovdata.no/dokument/NL/lov/1997-02-2819/KAPITTEL_10-1\#\%C2\%A725-6a Lest 14.1.2022. 
8. Legeforeningens høringsuttalelse Høring - utmåling og betaling av overtredelsesgebyr ilagt i medhold av (nye bestemmelser i) legemiddelloven $\S 28$ a, apotekloven $\S$ 9-6 og folketrygdloven $\S 25-6$ a-2. Sendt

22.6.2021. https://www.legeforeningen.no/contentassets/c7e2617eg6f44fb88eofe1415768832f/legeforeni ngens-hoeringssvar.pdf Lest 14.1.2022.

9. Braathen F. Fastleger provosert over at de kan bli bøtelagt ved feil med blå resepter. Aftenposten 13.1.2022. https://www.aftenposten.no/norge/i/Wj345G/fastleger-provosert-over-at-de-kan-bliboetelagt-ved-feil-med-blaa-resep Lest 14.1.2022.

Publisert: 20. januar 2022. Tidsskr Nor Legeforen. DOI:10.4045/tidsskr.22.0049

(C) Tidsskrift for Den norske legeforening 2023. Lastet ned fra tidsskriftet.no 26. april 2023. 